\title{
Growth and Instability in Area, Production and Export of Flowers in India
}

\author{
S. N. Patil ${ }^{1}$, J. S. Sonnad ${ }^{1}$, S. B. Mahajanashetti ${ }^{1}$, V. R. Kiresur ${ }^{2}$ and R. M. Hosamani ${ }^{3}$ \\ ${ }^{1}$ Department of Agribusiness Management, College of Agriculture, UAS, \\ Dharwad-580005, Karnataka, India \\ ${ }^{2}$ UAS, Dharwad-580005, Karnataka, India \\ ${ }^{3}$ Department of Horticulture, College of Agriculture, UAS, \\ Dharwad-580005, Karnataka, India \\ *Corresponding author
}

\begin{abstract}
A B S T R A C T
The present study has made an attempt to examine the growth and instability in the area, production, productivity and export of floriculture products in India during the phases such as Pre-NHM (1994-95 to 2004-05) and Post-NHM period (2005-06 to 2018-19) including overall study period (1994-95 to 2018-2019). The study is based on secondary data and used compound growth rate, coefficient of variation and Cuddy Della instability index. The results showed that in case of area and productivity, instability showed a decreasing trend from the Pre-NHM period (1994-95 to 2004-05) indicating positive effect of NHM scheme. In case of production, instability is slightly more in the Post-NHM period (2005-06 to 2018-19) than Pre-NHM period (1994-95 to 2004-05). Area, production and productivity of flowers in India showed positive and significant growth rate throughout all the periods of study. During this overall study period high instability in area was found in Maharashtra followed by Andhra Pradesh whereas West Bengal showed low instability. The production and productivity of flowers in India is consistent with more or less fluctuations in state wise growth during the studied period of time. The export of Indian flowers to all Zones was found to be increasing during overall study period but observed higher growth during Pre-NHM than Post-NHM period. The instability in export of flowers from India was higher in American, African, European and Oceanic Zone during Pre-NHM than Post-NHM period means instability has kept on declining in PostNHM period. For Asian and Unspecified Zones the instability has increased in the PostNHM period. During overall study period instability was highest in Unspecified Zone and least was observed for European Zone.
\end{abstract}

\section{Introduction}

Floriculture is becoming a booming industry in the world today. Human beings have been cultivating flowering plants for the purposes of ornamentation, use in religious rituals and in medicine from ancient times. Flowers make the best gifts by offering and exchange of flowers on all social occasions. Their uses for adornment of hair by women in some parts of 
the world and for home decoration have become an integral part of human living. They are used in places of worship. They provide food, perfumes and scents and can release stress and anxiety and also convey deepest emotions.

Floriculture has emerged as an important source of income for small and marginal farmers. Commercial floriculture has scaled new heights in the last decade to achieve record productions in the world over. The world has become more globalized in the recent past. The recent years have seen changes in the lifestyles of many people with increasing scope for flower utilization. Floriculture exports in particular have equally increased with trade liberalization in most countries. This increase in international trade has played a major role in bringing about the emergence of new markets in various parts of the world which has in turn influenced the emergence of new production centers to meet the growing demand. The total International Trade of floriculture in the year 2018 is of 6333,954.78 Metric tonnes which valued 20,233.52 Million US\$. Germany, Netherland, U. S. A., U. K. and France are the major players in the floriculture world market. India has exported 19726.56 Metric tonnes of floriculture products to the world for the worth of ₹ 57102.25lakhs in 2018-19.About 312 thousand hectares area was under cultivation in floriculture with the production of 2865 thousand tonnes of loose flowers and 817 thousand metric tonnes of cut flowers in 2018-19 in India. A lot of farmers in India have taken up the commercial growing of different flowers to take more advantage. Floriculture industry is considered a high income generating agribusiness and it can potentially be harnessed as a means of socioeconomic development. Thus, considering the importance and need, the present study has been taken with the specific objectives includes to examine the growth and instability of area, production and productivity of flowers in India and major flower growing states. And also to study the growth and instability in floriculture export of India.

\section{Materials and Methods}

\section{Analysis of data}

The time series data on area, production, productivity and export of Indian flowers for the period 1994-95 to 2018-19 were collected from annual publications of APEDA and website www.apeda.com, FAO year books, WTO website, and National Horticultural Board annual publications and website etc. The Government of India initiated the National Horticulture Mission (NHM) programme in the year 2004-05. In order to assess the effect of this programme on production and export of flowers from India, the data were divided into two time periods as Pre-NHM (1994-95 to 2004-05) and PostNHM (2005-06 to 2018-19) period. The collected data on export were grouped into six different Zones such as American, Asian, African, Ocean, European and Unspecified Zone. The major and regular importing countries from each Zone were considered, the rest of the countries from a particular Zone not mentioned by the sources were grouped under 'Unspecified'.

\section{Estimation of growth rates}

Trend analysis was done for state wise area under flowers, year wise production in metric tonnes and export values realized from exports. The growth quantities were analyzed by using the following linear trend equation.

$\mathrm{Y}=\mathrm{a}+\mathrm{bx}+\mathrm{e}$

Where, $\mathrm{Y}=$ Dependent variable 
$\mathrm{a}=$ Intercept or constant

$\mathrm{b}=$ Regression / Trend coefficient

$\mathrm{x}=$ Number of years

$\mathrm{e}=$ error term

The exponential growth rates were worked out using the exponential growth function of the following form,

$\mathrm{Y}=a b^{\mathrm{x}} \mathrm{e}^{\mathrm{u}}$

Where,

$\mathrm{Y}=$ Dependent variable

$\mathrm{a}=$ Intercept

$\mathrm{b}=$ Regression coefficient

$\mathrm{x}=$ Number of years

$\mathrm{e}^{\mathrm{u}}=$ Error term

The compound growth rate was estimated by using the semi-logarithmic form of the equation (II) as below:

$\log Y=\log a+t \log b$

Then, the per cent compound growth rate $(\mathrm{g})$ was computed using:

$g=($ Antilog of $\log b-1) \times 100$

\section{Instability analysis}

Instability index was used to examine the extent of variation and risk involved in the parameter such as area, production, productivity and export of flowers. In order to study variability, an instability index was used as a measure of variability. The coefficient of variation $(\mathrm{CV})$ was calculated by using the following formula:

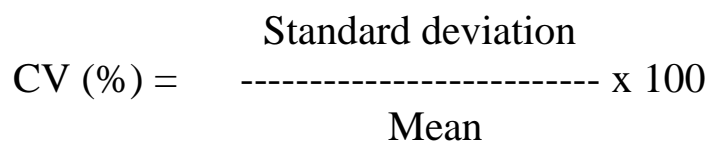

The trend coefficient was tested for its significance. Whenever, the trend coefficient was found to be significant, the variation around the trend rather than variation around mean was used as an index of instability. The formula suggested by Cuddy and Della (1978) was used to complete the degree of variation around the trend.

Instability index $(\%)=\mathrm{CV} \times \sqrt{ }\left(1-\mathrm{R}^{2}\right)$

Where,

$\mathrm{CV}=$ Coefficient of variation

$\mathrm{R}^{2}=$ Coefficient of multiple determination obtained from the time series

It is a better measure to capture instability in area, production and export in agriculture sector. A low value of this index indicates the low instability.

\section{Results and Discussion}

\section{Growth and instability in Area, production} and productivity of flowers in India

The trends in area, production, productivity and instability analysis for area, production, productivity of flowers in India for the period from 1994-95 to 2018-19 are periodically depicted in Table 1.

In order to identify the significant role and the economic status of floriculture in Indian economy, an attempt has been made at period wise analysis of growth coefficient of variation and instability during the study period.

The Table depicted that during Pre-NHM period, area, production and productivity of flowers in India showed positive and significant growth rate with 6.09, 9.54 and 3.87 per cent growth respectively. As well as in Post-NHM period, they showed positive and significant growth with 7.35, 10.67 and 3.10 per cent respectively. The production of flowers showed highly significant growth rate in Post-NHM period. 
The Table depicted that the growth in area of flowers is positive and significant at the rate of 7.42 per cent for the overall study period. The production of flowers also showed the positive and highly significant growth rate at 9.79 per cent. The productivity of flowers showed the positive and significant growth at the rate of 2.08 per cent per annum during overall study period.

It could be observed from the table that average flowers area during the overall period was 167.83 thousand ha. while it was 89.84 thousand ha. and 229.11 thousand ha during the Pre-NHM period and Post-NHM period respectively.

The average production and productivity of flowers were 1106.88 thousand metric tonnes and 6.20 metric tonnes per hectare in the period 1994-95 to 2018-19 respectively.

The coefficient of variation for area of floriculture was maximum during overall study period i. e. 51.71 per cent while PreNHM period showed less variation i.e. 20.28 per cent than Post-NHM period indicated by coefficient of variation 29.15 per cent. Coefficient of variation for production was also higher during overall study period i. e. 67.45 per cent. Coefficient of variation for production in Post-NHM period (40.99\%) was higher than Pre-NHM period $(30.90 \%)$. Similarly, productivity shows a slightly increased CV of Pre-NHM period $(21.65 \%)$ than the overall study period $(21.58 \%)$ and Post-NHM period (18.16\%). Thus, the production of floriculture in India showed consistent growth during the overall period of study i.e. 1994-95 to 2018- 2019.

The instability of area was higher in overall study period i.e. 7.50 per cent. It was 7.28 per cent in Pre-NHM period and 6.84 per cent in Post-NHM period. The instability of production in Post-NHM period was 14.10 per cent which is higher than Pre-NHM period $(10.42 \%)$ and overall study period $(13.16 \%)$. The instability in the productivity was higher in the Pre-NHM period with 16.44 per cent when compared to Post-NHM period with 12.76 per cent. In the overall study period instability in the productivity was 14.84 per cent.

From the Table it is observed that there is positive and significant growth in all area, production and productivity of flowers. Area, production and productivity of flowers in India showed positive and significant growth rate throughout all the periods of study. In case of area and productivity, instability showed a decreasing trend from the Pre-NHM period (1994-95 to 2004-05) indicating positive effect of NHM scheme. The study revealed that there is a less variation and instability in area, production and productivity of flowers in India thus, the production of flowers is observed consistent with slight fluctuations.

\section{State wise growth and instability of area of flowers in India}

The five major flowers growing states in India namely Tamil Nadu, West Bengal, Andhra Pradesh, Karnataka and Maharashtra were considered for the study. It is found from the Table 2 that the compound growth rate of area under flowers in other minor flowers producing states was estimated around 13.57 per cent during overall period under the study. The estimated growth rate of area of Maharashtra was registered at 8.34 per cent, 5.30 per cent and 4.28 per cent in the PreNHM, Post-NHM and overall study period. The overall compound growth rate of area at different states in India during 1994-95 to 2018-19 was estimated around 7.42 per cent, which means the area was increased annually by 7.42 per cent over the study period. In Karnataka and other minor flowers growing 
states highest growth rate in area under flowers was found in the Post-NHM period with 3.08 per cent and14.90 per cent respectively. The area under flowers in Tamil Nadu, West Bengal, Andhra Pradesh and Maharashtra shown high growth in the PreNHM period i.e. 5.09, 4.31, 8.67 and 8.34 per cent respectively as compared to the PostNHM period i.e. 2.96, 2.67, 0.69 and -5.30 per cent respectively.

From the Table 2, it was revealed that highest $\mathrm{CV}$ was observed in minor flowers producing states during overall study period with 90.60 per cent followed by Andhra Pradesh, Maharashtra, Tamil Nadu, Karnataka and West Bengal with 63.84, 54.02, 39.25, 29.53 and 27.90 per cent respectively. Thus, it showed during overall study period there was greater variability in the area of flowers in minor flower producing states. During PreNHM period the CV was highest in minor flowers producing states with 43.04 per cent followed by Andhra Pradesh, Maharashtra, Tamil Nadu, West Bengal and Karnataka with 27.13, 27.06, 16.85, 16.84 and 7.04 per cent respectively. Thus, it showed during PreNHM period also there was greater variability in the area of flowers in minor flower producing states and Karnataka was stable state. Minor flower producing states $(57.10 \%)$ showed highest CV during Post-NHM period followed by Andhra Pradesh, Maharashtra, Tamil Nadu, Karnataka and West Bengal with 49.78, 39.14, 27.79, 24.86 and 13.22 per cent respectively. Thus, it showed during PostNHM period there was greater variability in the area of flowers in minor flower producing states and less variability in Karnataka.

The instability analysis showed that high instability was found in other minor flowers growing states in the Pre-NHM period with 24.49 per cent followed by Maharashtra, West Bengal, Andhra Pradesh, Karnataka and Tamil Nadu with 11.52 per cent, 9.85 per cent, 9.09 per cent, 6.74 per cent and 4.53 per cent respectively. In case of Post-NHM period high instability was found in Andhra Pradesh followed by Maharashtra, Tamil Nadu, Karnataka, West Bengal and other minor flowers growing states with 49.63 per cent, 33.81 per cent,23.88 per cent, 19.63 per cent, 8.01 per cent and 7.74 per cent respectively.

It can be understood from the analysis that there was a positive and significant growth with instability in total area in all major producing states in India over the past 25 years. During this overall study period, high instability was found in Maharashtra with 44.36 per cent followed by Andhra Pradesh with 39.03 per cent. West Bengal showed low instability with 9.24 per cent.

\section{State wise growth and instability of production of flowers in India}

The results of growth, coefficient of variation and instability in production under flowers in major flowers growing states in India were presented in the Table.3. From the Table.3, it was observed that a compound growth rate for production of flowers in other minor states was positively increased with 14.26 per cent in the overall study period. It also showed that the growth of flowers production during PreNHM period and Post-NHM period in the minor or other states also showed positive and highly significant growth with the growth rate of 17.37 and 14.15 per cent respectively. West Bengal was the state with highest growth rate during overall study period with 8.79 per cent followed by Tamil Nadu, Andhra Pradesh and Karnataka with the growth rate of $8.36,7.60$ and 3.48 per cent respectively. During Pre-NHM period of study, West Bengal showed highest growth with 18.30 per cent followed by Andhra Pradesh and Karnataka with 11.55 and 3.96 per cent growth respectively whereas Tamil Nadu and Maharashtra showed insignificant 
growth. Similarly, During Post-NHM period Tamil Nadu showed highest growth with 7.82 per cent followed by West Bengal and Karnataka with 4.66 and 1.69 per cent growth whereas Andhra Pradesh showed insignificant growth. Maharashtra showed negative growth rate i.e. -4.87 per cent during this period.

From the Table 3, it was revealed that CV was observed highest in minor flowers producing states during overall study period with 87.44 per cent followed by Andhra Pradesh, Tamil Nadu, Maharashtra, West Bengal and Karnataka with 83.83, 59.39, 57.80, 48.99 and 25.55 per cent respectively. Thus, it showed during overall study period there was greater variability in the production of flowers in minor flower producing states and Karnataka was the stable state. During Pre-NHM period the CV was highest in minor flowers producing states with 85.99 per cent followed by Andhra Pradesh, West Bengal, Maharashtra, Tamil Nadu and Karnataka with 61.20, 53.27, 51.83, 43.93 and 13.18 per cent respectively. Thus, during Pre-NHM period it showed there was greater variability in the production of flowers in minor flower producing states and Karnataka was stable state. Andhra Pradesh (67.31\%) showed highest CV during Post-NHM period followed by minor flower producing states, Maharashtra, Tamil Nadu, West Bengal and Karnataka with 53.16, 39.28, 35.16, 18.51 and 11.07 per cent respectively. Thus, it showed during Post-NHM period, there was greater variability in the production of flowers in Andhra Pradesh and Karnataka was stable state.

The instability index of production of flowers showed that high instability was found in other minor flowers growing states in the PreNHM period with 54.11 per cent followed by Andhra Pradesh, Maharashtra, Tamil Nadu, West Bengal and Karnataka and with 51.58 per cent, 50.62 per cent, 43.84 per cent, 18.10 per cent and 4.75 per cent respectively. During Post-NHM period, high instability was found in Andhra Pradesh with 64.30 per cent followed by Maharashtra, other minor flowers growing states, Tamil Nadu, Karnataka and West Bengal with 34.85 per cent, 27.13 per cent, and 12.95 per cent, 8.81 per cent and 4.18 per cent respectively. During overall study period, high instability was found in Andhra Pradesh with 71.18 per cent followed by Maharashtra, Tamil Nadu, other minor flowers growing states, West Bengal and Karnataka with 55.31, 37.19, 31.07, 18.56 and 9.06 per cent respectively.

Thus, the study showed that the production of flowers in India is consistent with more or less fluctuations in state wise growth during the study period.

\section{State wise growth and instability of productivity of flowers in India}

The results of growth, coefficient of variation and instability in productivity under flowers in major producing states in India were presented in Table 4.

From the Table 4, it was observed that a compound growth rate for productivity of flowers in West Bengal showed significant and highest growth rate during overall study period with 4.74 per cent followed by Tamil Nadu with the growth rate of 3.66 per cent. During Pre-NHM period of study, West Bengal showed highest and significant growth with 13.42 per cent followed by Karnataka with 3.29 per cent. Similarly, during PostNHM period, Tamil Nadu and West Bengal showed significant growth with 4.72 and 1.94 per cent respectively.

From the Table.4, it was revealed that CV was observed highest in Andhra Pradesh during overall study period with 54.72 per cent followed by other minor states, Tamil 
Nadu, Maharashtra, West Bengal and Karnataka with 45.96, 40.37, 33.66, 31.11 and 12.45 per cent respectively. Thus, it showed that during overall study period, there was greater variability in the productivity of flowers in Andhra Pradesh and Karnataka was the stable state. During Pre-NHM period, the $\mathrm{CV}$ was highest in minor flowers producing states with 56.16 per cent followed by Maharashtra, Andhra Pradesh, West Bengal, Tamil Nadu and Karnataka with 50.73, 49.06, 40.21, 35.05 and 12.31 per cent respectively. Thus, it showed during Pre-NHM period, there was greater variability in the productivity of flowers in minor flower producing states and Karnataka was stable state. Andhra Pradesh (56.87\%) showed highest CV during Post-NHM period followed by minor flower producing states, Tamil Nadu, Karnataka, West Bengal and Maharashtra with 38.21, 33.56, 11.70, 10.38 and 7.90 per cent respectively. Thus, it showed that there was greater variability in the productivity of flowers in Andhra Pradesh and Karnataka was stable state during PostNHM period.

The instability index of productivity of flowers showed that during overall study period high instability was found in Andhra Pradesh in the Pre-NHM period with 54.28 per cent followed by other minor flowers growing states, Tamil Nadu, Maharashtra, West Bengal and Karnataka with 45.73 per cent, 35.44 per cent, 33.51 per cent, 17.76 per cent and 11.92 per cent respectively. During Post-NHM period, high instability was found in Andhra Pradesh with 54.99 per cent followed by other minor flowers growing states, Tamil Nadu, Karnataka, Maharashtra and West Bengal with 38.09 per cent, 26.74 per cent, and 10.64 per cent, 7.70 per cent and 7.53 per cent respectively. During Pre-NHM period, high instability was found in other minor flowers growing states with 54.90 per cent followed by Andhra Pradesh,
Maharashtra, Tamil Nadu, West Bengal and Karnataka with 48.27, 48.10, 34.45, 17.06 and 5.54 per cent respectively.

Thus, the study showed that the productivity of flowers in India is increasing with more or less fluctuations in state wise growth during the study period.

\section{Growth and instability in Zone wise export of flowers from India}

The results of growth, coefficient of variation and instability in Zone wise export of flowers from India were presented in the Table 5. The value of Indian floriculture exports to American Zone registered the significant compound growth rate of 18.02 per cent in Pre-NHM period and 6.09 per cent in PostNHM period. At an overall level, the estimated compound growth rate of export of floriculture to American Zone from India registered at 10.90 per cent per annum. The co-efficient of variations in export value of Indian floriculture exports to American Zone were 65.76 per cent, 29.41 per cent and 62.77 per cent during Pre-NHM period, Post-NHM period and overall study period respectively. The instability of export value of Indian floriculture exports to American Zone were 25.95 per cent, 14.09 per cent and 20.59 per cent during Pre-NHM period, Post-NHM period and overall study period respectively.

The Indian flowers export to African Zone was growing significantly at the rate of 26.14 per cent and 22.51 per cent per annum during Pre-NHM period and overall study period respectively. In the Post-NHM period export represented the compound growth rate of 4.57 per cent per annum. The co-efficient of variations in export value of Indian floriculture exports to African Zone were 96.36 per cent, 41.62 per cent and 97.98 per cent during Pre-NHM period, Post-NHM period and overall study period respectively. 
The Indian floriculture exports to African Zone showed 39.55 per cent, 36.69 per cent and 51.29 per cent of instability during PreNHM period, Post-NHM period and overall study period respectively.

The Indian flowers export to Asian Zone was growing significantly at the rate of 19.06 per cent and 11.51 per cent per annum during PreNHM period and overall study period respectively. The co-efficient of variations in export value of Indian floriculture exports to Asian Zone were 52.25 per cent, 77.76 per cent and 106.84 per cent during Pre-NHM period, Post-NHM period and overall study period respectively. The Indian floriculture exports to Asian Zone showed 20.03 per cent, 75.95 per cent and 58.60 per cent of instability during Pre-NHM period, Post-
NHM period and overall study period respectively.

The Indian flowers export to European Zone was growing significantly at the rate of 19.54 per cent, 4.16 per cent and 10.36 per cent per annum during Pre-NHM period, Post-NHM period and overall study period respectively. The co-efficient of variations in export value of Indian floriculture exports to European Zone were 55.59 per cent, 18.72 per cent and 55.72 per cent during Pre-NHM period, PostNHM period and overall study period respectively. The Indian floriculture exports to European Zone showed 15.13 per cent, 9.38 per cent and 20.10 per cent of instability during Pre-NHM period, Post-NHM period and overall study period respectively.

Table.1 Growth and instability in Area, production and productivity of flowers in India

\begin{tabular}{|c|c|c|c|c|c|}
\hline SI. & \multicolumn{2}{|c|}{ Particulars } & \multirow{2}{*}{$\begin{array}{l}\text { Pre-NHM } \\
\text { period } \\
89.84\end{array}$} & \multirow{2}{*}{$\begin{array}{l}\text { Post-NHM } \\
\text { period } \\
229.11\end{array}$} & \multirow{2}{*}{$\begin{array}{l}\text { Overall } \\
\text { period } \\
167.83\end{array}$} \\
\hline \multirow[t]{5}{*}{1} & \multirow[t]{5}{*}{ Area } & Average ('000' ha.) & & & \\
\hline & & CAGR & $6.09 * * *$ & $7.35 * * *$ & $7.42 * * *$ \\
\hline & & $\mathrm{CV}$ & 20.28 & 29.15 & 51.71 \\
\hline & & $\mathrm{R}^{2}$ & $0.871 * * *$ & $0.945 * * *$ & $0.979 * * *$ \\
\hline & & Cuddy DellaIndex & 7.28 & 6.84 & 7.50 \\
\hline \multirow[t]{5}{*}{2} & \multirow[t]{5}{*}{ Production } & Average ('000' MT) & 485.05 & 1595.46 & 1106.88 \\
\hline & & CAGR & $9.54 * * *$ & $10.67 * * *$ & $9.79 * * *$ \\
\hline & & $\mathrm{CV}$ & 30.90 & 40.99 & 67.45 \\
\hline & & $\mathrm{R}^{2}$ & $0.886 * * *$ & $0.882 * * *$ & $0.962 * * *$ \\
\hline & & Cuddy Della Index & 10.42 & 14.10 & 13.16 \\
\hline \multirow[t]{5}{*}{3} & \multirow[t]{5}{*}{ Productivity } & Average & 5.52 & 6.74 & 6.20 \\
\hline & & CAGR & $3.87 * *$ & $3.10 * * *$ & $2.08 * * *$ \\
\hline & & $\mathrm{CV}$ & 21.65 & 18.16 & 21.58 \\
\hline & & $\mathrm{R}^{2}$ & $0.423 * *$ & $0.507 * * *$ & $0.527 * * *$ \\
\hline & & Cuddy Della Index & 16.44 & 12.76 & 14.84 \\
\hline
\end{tabular}

Note: $* * *, * * \& *$ significance at $1 \%, 5 \%$ and $10 \%$ level respectively. 
Table.2 State wise growth and instability of area of flowers in India

\begin{tabular}{|c|c|c|c|c|c|}
\hline Sl. No. & States & Particulars & $\begin{array}{c}\text { Pre-NHM } \\
\text { period }\end{array}$ & $\begin{array}{c}\text { Post-NHM } \\
\text { period }\end{array}$ & $\begin{array}{l}\text { Overall } \\
\text { period }\end{array}$ \\
\hline \multirow[t]{4}{*}{1} & \multirow[t]{4}{*}{ Tamil Nadu } & CAGR & $5.09 * * *$ & $2.96 *$ & $4.53 * * *$ \\
\hline & & $\mathrm{CV}$ & 16.85 & 27.79 & 39.25 \\
\hline & & $\mathrm{R}^{2}$ & $0.928 * * *$ & $0.262 *$ & $0.802 * * *$ \\
\hline & & Cuddy Della Index & 4.53 & 23.88 & 17.46 \\
\hline \multirow[t]{4}{*}{2} & \multirow[t]{4}{*}{ West Bengal } & CAGR & $4.31 * * *$ & $2.67 * * *$ & $3.87 * * *$ \\
\hline & & $\mathrm{CV}$ & 16.84 & 13.22 & 27.90 \\
\hline & & $\mathrm{R} 2$ & $0.658 * * *$ & $0.633 * * *$ & $0.890 * * *$ \\
\hline & & Cuddy Della Index & 9.85 & 8.01 & 9.24 \\
\hline \multirow[t]{4}{*}{3} & \multirow[t]{4}{*}{ Andhra Pradesh } & CAGR & $8.67 * * *$ & $0.69 \mathrm{NS}$ & $5.91 * * *$ \\
\hline & & $\mathrm{CV}$ & 27.13 & 49.78 & 63.84 \\
\hline & & $\mathrm{R}^{2}$ & $0.888 * * *$ & $0.006 \mathrm{NS}$ & $0.626 * * *$ \\
\hline & & Cuddy Della Index & 9.09 & 49.63 & 39.03 \\
\hline \multirow[t]{4}{*}{4} & \multirow[t]{4}{*}{ Karnataka } & CAGR & $0.65 \mathrm{NS}$ & $3.08 * *$ & $2.93 * * *$ \\
\hline & & $\mathrm{CV}$ & 7.04 & 24.86 & 29.53 \\
\hline & & $\mathrm{R}^{2}$ & $0.083 \mathrm{NS}$ & $0.376 * *$ & $0.703 * * *$ \\
\hline & & Cuddy Della Index & 6.74 & 19.63 & 16.09 \\
\hline \multirow[t]{4}{*}{5} & \multirow[t]{4}{*}{ Maharashtra } & CAGR & $8.34 * * *$ & $-5.30 *$ & $4.28 * * *$ \\
\hline & & $\mathrm{CV}$ & 27.06 & 39.14 & 54.02 \\
\hline & & $\mathrm{R}^{2}$ & $0.819 * * *$ & $0.254 *$ & $0.326 * * *$ \\
\hline & & Cuddy Della Index & 11.52 & 33.81 & 44.36 \\
\hline \multirow[t]{4}{*}{6} & \multirow[t]{4}{*}{ Other states } & CAGR & $13.22 * * *$ & $14.90 * * *$ & $13.57 * * *$ \\
\hline & & $\mathrm{CV}$ & 43.04 & 57.10 & 90.60 \\
\hline & & $\mathrm{R}^{2}$ & $0.676 * * *$ & $0.982 * * *$ & $0.958 * * *$ \\
\hline & & Cuddy Della Index & 24.49 & 7.74 & 18.65 \\
\hline
\end{tabular}

Note: $* * *, * * \& *$ significance at $1 \%, 5 \%$ and $10 \%$ level respectively.

NS non-significant 
Table.3 State wise growth and instability of production of flowers in India

\begin{tabular}{|c|c|c|c|c|c|}
\hline Sl. No. & States & Particulars & $\begin{array}{c}\text { Pre-NHM } \\
\text { period }\end{array}$ & $\begin{array}{l}\text { Post-NHM } \\
\text { period }\end{array}$ & $\begin{array}{l}\text { Overall } \\
\text { period }\end{array}$ \\
\hline \multirow[t]{4}{*}{1} & \multirow[t]{4}{*}{ Tamil Nadu } & CAGR & $1.32 \mathrm{NS}$ & $7.82 * * *$ & $8.36 * * *$ \\
\hline & & $\mathrm{CV}$ & 43.93 & 35.16 & 59.39 \\
\hline & & $\mathrm{R}^{2}$ & $0.004 \mathrm{NS}$ & $0.864 * * *$ & $0.608 * * *$ \\
\hline & & Cuddy Della Index & 43.84 & 12.95 & 37.19 \\
\hline \multirow[t]{4}{*}{2} & \multirow[t]{4}{*}{ West Bengal } & CAGR & $18.30 * * *$ & $4.66 * * *$ & $8.79^{* * *}$ \\
\hline & & $\mathrm{CV}$ & 53.27 & 18.51 & 48.99 \\
\hline & & $\mathrm{R} 2$ & $0.885 * * *$ & $0.949 * * *$ & $0.857 * * *$ \\
\hline & & Cuddy Della Index & 18.10 & 4.18 & 18.56 \\
\hline \multirow[t]{4}{*}{3} & \multirow[t]{4}{*}{ Andhra Pradesh } & CAGR & $11.55 *$ & $8.17 \mathrm{NS}$ & $7.60 * * *$ \\
\hline & & $\mathrm{CV}$ & 61.20 & 67.31 & 83.83 \\
\hline & & $\mathrm{R}^{2}$ & $0.290 *$ & $0.088 \mathrm{NS}$ & $0.279 * * *$ \\
\hline & & Cuddy Della Index & 51.58 & 64.30 & 71.18 \\
\hline \multirow[t]{4}{*}{4} & \multirow[t]{4}{*}{ Karnataka } & CAGR & $3.96^{* * *}$ & $1.69 * *$ & $3.48 * * *$ \\
\hline & & $\mathrm{CV}$ & 13.18 & 11.07 & 25.55 \\
\hline & & $\mathrm{R}^{2}$ & $0.870 * * *$ & $0.367 * *$ & $0.874 * * *$ \\
\hline & & Cuddy Della Index & 4.75 & 8.81 & 9.06 \\
\hline \multirow[t]{4}{*}{5} & \multirow[t]{4}{*}{ Maharashtra } & CAGR & $-14.84 \mathrm{NS}$ & $-4.87 *$ & $7.34 \mathrm{NS}$ \\
\hline & & $\mathrm{CV}$ & 51.83 & 39.28 & 57.80 \\
\hline & & $\mathrm{R}^{2}$ & $0.046 \mathrm{NS}$ & $0.213 *$ & $0.084 \mathrm{NS}$ \\
\hline & & Cuddy Della Index & 50.62 & 34.85 & 55.31 \\
\hline \multirow[t]{4}{*}{6} & \multirow[t]{4}{*}{ Other states } & CAGR & $17.37 * * *$ & $14.15 * * *$ & $14.26 * * *$ \\
\hline & & $\mathrm{CV}$ & 85.99 & 53.16 & 87.44 \\
\hline & & $\mathrm{R}^{2}$ & $0.604 * * *$ & $0.740 * * *$ & $0.874 * * *$ \\
\hline & & Cuddy Della Index & 54.11 & 27.13 & 31.07 \\
\hline
\end{tabular}

Note: $* * *, * * \& *$ significance at $1 \%, 5 \%$ and $10 \%$ level respectively.

NS non-significant 
Table.4 State wise growth and instability of productivity of flowers in India

\begin{tabular}{|c|c|c|c|c|c|}
\hline Sl. No. & States & Particulars & $\begin{array}{c}\text { Pre-NHM } \\
\text { period }\end{array}$ & $\begin{array}{c}\text { Post-NHM } \\
\text { period }\end{array}$ & $\begin{array}{c}\text { Overall } \\
\text { period }\end{array}$ \\
\hline \multirow[t]{4}{*}{1} & \multirow[t]{4}{*}{ Tamil Nadu } & CAGR & $-3.59 \mathrm{NS}$ & $4.72 * *$ & $3.66 * *$ \\
\hline & & $\mathrm{CV}$ & 35.05 & 33.56 & 40.37 \\
\hline & & $\mathrm{R}^{2}$ & $0.034 \mathrm{NS}$ & $0.365 * *$ & $0.229 * *$ \\
\hline & & Cuddy Della Index & 34.45 & 26.74 & 35.44 \\
\hline \multirow[t]{4}{*}{2} & \multirow[t]{4}{*}{ West Bengal } & CAGR & $13.42 * * *$ & $1.94 * * *$ & $4.74 * * *$ \\
\hline & & $\mathrm{CV}$ & 40.21 & 10.38 & 31.11 \\
\hline & & $\mathrm{R} 2$ & $0.820 * * *$ & $0.474 * * *$ & $0.674 * * *$ \\
\hline & & Cuddy Della Index & 17.06 & 7.53 & 17.76 \\
\hline \multirow[t]{4}{*}{3} & \multirow[t]{4}{*}{ Andhra Pradesh } & CAGR & $2.65 \mathrm{NS}$ & $7.44 \mathrm{NS}$ & $1.60 \mathrm{NS}$ \\
\hline & & $\mathrm{CV}$ & 49.06 & 56.87 & 54.72 \\
\hline & & $\mathrm{R}^{2}$ & $0.032 \mathrm{NS}$ & $0.065 \mathrm{NS}$ & $0.016 \mathrm{NS}$ \\
\hline & & Cuddy Della Index & 48.27 & 54.99 & 54.28 \\
\hline \multirow[t]{4}{*}{4} & \multirow[t]{4}{*}{ Karnataka } & CAGR & $3.29 * * *$ & $-1.35 \mathrm{NS}$ & $0.53 \mathrm{NS}$ \\
\hline & & $\mathrm{CV}$ & 12.31 & 11.70 & 12.45 \\
\hline & & $\mathrm{R}^{2}$ & $0.798 * * *$ & $0.173 \mathrm{NS}$ & $0.083 \mathrm{NS}$ \\
\hline & & Cuddy Della Index & 5.54 & 10.64 & 11.92 \\
\hline \multirow[t]{4}{*}{5} & \multirow[t]{4}{*}{ Maharashtra } & CAGR & $-11.33 \mathrm{NS}$ & $0.45 \mathrm{NS}$ & $1.64 \mathrm{NS}$ \\
\hline & & $\mathrm{CV}$ & 50.73 & 7.90 & 33.66 \\
\hline & & $\mathrm{R}^{2}$ & $0.101 \mathrm{NS}$ & $0.049 \mathrm{NS}$ & $0.009 \mathrm{NS}$ \\
\hline & & Cuddy Della Index & 48.10 & 7.70 & 33.51 \\
\hline \multirow[t]{4}{*}{6} & \multirow[t]{4}{*}{ Other states } & CAGR & $3.67 \mathrm{NS}$ & $-0.66 \mathrm{NS}$ & $0.61 \mathrm{NS}$ \\
\hline & & CV & 56.16 & 38.21 & 45.96 \\
\hline & & $\mathrm{R}^{2}$ & $0.044 \mathrm{NS}$ & $0.006 \mathrm{NS}$ & $0.010 \mathrm{NS}$ \\
\hline & & Cuddy Della Index & 54.90 & 38.09 & 45.73 \\
\hline
\end{tabular}

Note: $* * *, * * \& *$ significance at $1 \%, 5 \%$ and $10 \%$ level respectively.

NS non-significant 
Table.5 Growth and instability in Zone wise export of flowers from India

\begin{tabular}{|c|c|c|c|c|c|}
\hline Sl. No. & Zone & Particulars & $\begin{array}{l}\text { Pre-NHM } \\
\text { period }\end{array}$ & $\begin{array}{c}\text { Post-NHM } \\
\text { period }\end{array}$ & $\begin{array}{l}\text { Overall } \\
\text { period }\end{array}$ \\
\hline \multirow[t]{4}{*}{1} & \multirow[t]{4}{*}{ American } & CAGR & $18.02 * * *$ & $6.09 * * *$ & $10.90 * * *$ \\
\hline & & $\mathrm{CV}$ & 65.76 & 29.41 & 62.77 \\
\hline & & $\mathrm{R}^{2}$ & $0.844 * * *$ & $0.771 * * *$ & $0.892 * * *$ \\
\hline & & Cuddy Della Index & 25.95 & 14.09 & 20.59 \\
\hline \multirow[t]{4}{*}{2} & \multirow[t]{4}{*}{ African } & CAGR & $26.14 * * *$ & $-4.57 *$ & $22.51 * * *$ \\
\hline & & $\mathrm{CV}$ & 96.36 & 41.62 & 97.98 \\
\hline & & $\mathrm{R} 2$ & $0.832 * * *$ & $0.223 *$ & $0.726 * * *$ \\
\hline & & Cuddy Della Index & 39.55 & 36.69 & 51.29 \\
\hline \multirow[t]{4}{*}{3} & \multirow[t]{4}{*}{ Asian } & CAGR & $19.06 * * *$ & $2.96 \mathrm{NS}$ & $11.51 * * *$ \\
\hline & & $\mathrm{CV}$ & 52.25 & 77.76 & 106.84 \\
\hline & & $\mathrm{R}^{2}$ & $0.853 * * *$ & $0.046 \mathrm{NS}$ & $0.699 * * *$ \\
\hline & & Cuddy Della Index & 20.03 & 75.95 & 58.60 \\
\hline \multirow[t]{4}{*}{4} & \multirow[t]{4}{*}{ European } & CAGR & $19.54 * * *$ & $4.16 * * *$ & $10.36 * * *$ \\
\hline & & $\mathrm{CV}$ & 55.59 & 18.72 & 55.72 \\
\hline & & $\mathrm{R}^{2}$ & $0.926 * * *$ & $0.749 * * *$ & $0.870 * * *$ \\
\hline & & Cuddy Della Index & 15.13 & 9.38 & 20.10 \\
\hline \multirow[t]{4}{*}{5} & \multirow[t]{4}{*}{ Oceanic } & CAGR & $29.17 * * *$ & $9.30 * * *$ & $16.46 * * *$ \\
\hline & & $\mathrm{CV}$ & 79.89 & 39.05 & 79.89 \\
\hline & & $\mathrm{R}^{2}$ & $0.845 * * *$ & $0.842 * * *$ & $0.889 * * *$ \\
\hline & & Cuddy Della Index & 31.47 & 15.53 & 26.62 \\
\hline \multirow[t]{4}{*}{6} & \multirow[t]{4}{*}{ Unspecified } & CAGR & $72.65 * * *$ & $-9.05 \mathrm{NS}$ & $33.25 * * *$ \\
\hline & & $\mathrm{CV}$ & 115.55 & 305.88 & 408.47 \\
\hline & & $\mathrm{R}^{2}$ & $0.551 * * *$ & $0.103 \mathrm{NS}$ & $0.547 * * *$ \\
\hline & & Cuddy Della Index & 77.43 & 289.76 & 274.93 \\
\hline
\end{tabular}

Note: $* * *, * * \& *$ significance at $1 \%, 5 \%$ and $10 \%$ level respectively.

NS non-significant

The Indian flowers export to Oceanic Zone was growing significantly at the rate of 29.17 per cent, 9.30 per cent and 16.46 per cent per annum during Pre-NHM period, Post-NHM period and overall study period respectively. The co-efficient of variations in export value of Indian floriculture exports to Oceanic Zone were 79.89 per cent, 39.05 per cent and 79.89 per cent during Pre-NHM period, Post-NHM period and overall study period respectively. The Indian floriculture exports to Oceanic Zone showed 31.47 per cent, 15.53 per cent and 26.62 per cent of instability during PreNHM period, Post-NHM period and overall study period respectively.

The instability in export of flowers from India was higher in American, African, European and Oceanic Zone during Pre-NHM period than Post-NHM period means instability has kept on declining in Post-NHM period. For Asian and Unspecified Zones the instability has declined in the Post-NHM period. During overall study period instability was highest in 
Unspecified Zone and least was observed for European Zone.

In conclusion, the growth rate of Indian flowers in area, production and productivity were found to be increasing. The growth rate in area, production and productivity was $7.42,9.79$ and 2.08 per cent respectively during overall study period. Area, production and productivity of flowers showed higher significant growth rate in Post-NHM period than Pre-NHM period. There is a less variation and instability in area, production and productivity of flowers thus, the production of flowers in India is observed consistent with slight fluctuations.

There was a positive and significant growth with instability in total area in all major flowers producing states in India over the past 25 years. During this overall study period, high instability in area was found in Maharashtra with 44.36 per cent followed by Andhra Pradesh with 39.03 per cent. West Bengal showed low instability with 9.24 per cent. Growth rate for production of flowers in other minor states was highest and positively increased with 14.26 per cent in the overall study period.

West Bengal, Andhra Pradesh and Karnataka showed higher growth in production of flowers during Pre-NHM period than Post-NHM period whereas Tamil Nadu and Maharashtra showed higher growth in Post-NHM period than PreNHM period. Tamil Nadu, Andhra Pradesh and Maharashtra showed increasing trend in PostNHM period than Pre-NHM period in productivity. The production and productivity of flowers in India is consistent with more or less fluctuations in state wise growth during the study period of time.

The export of Indian flowers to all Zones was found to be increasing during overall study period but observed higher growth during PreNHM period than Post-NHM period. Unspecified Zone showed negative and insignificant growth rate in Post-NHM period. The instability in export of flowers from India was higher in American, African, European and Oceanic Zone during Pre-NHM period than Post-NHM period, means instability has kept on declining in Post-NHM period. For, Asian and Unspecified Zones the instability has increased in the Post-NHM period. During overall study period instability was highest in Unspecified Zone and least was observed for European Zone.

\section{References}

Cuddy, J.D.A. and Della Valle, P.A. 1978, Measuring the instability of time series data. Oxford Bull. Econs. and Stats., 40(1): 79-84

Misra D. and Ghosh S., 2016, Growth and export status of Indian floriculture review. Agric. Reviews., 37 (1): 77-80.

Mokashi, P. and Hosamani, S. B., 2014, Growth and instability analysis of Indian grapes export. Agric. Update., 9(1): 132-135.

Nagpure S., Mhaske A., and Kokate S. 2019. Trade Performance of Banana in India Internat. J. of Research and Review, 6 (5): 113-123.

Raman, 2016, Analysis of growth trends in production and export of Indian cut flowers with special reference to contribution of Maharashtra. Int. J. of Multidisciplinary Res. and Develop., 3 (7): $71-75$

www.apeda.com

www.indiastat.com.

www.nhb.gov.in

\section{How to cite this article:}

Patil, S. N., J. S. Sonnad, S. B. Mahajanashetti, V. R. Kiresur and Hosamani, R.M. 2020. Growth and Instability in Area, Production and Export of Flowers in India. Int.J.Curr.Microbiol.App.Sci. 9(08): 2429-2441. doi: https://doi.org/10.20546/ijcmas.2020.908.278 